EASTERN EUROPEAN JOURNAL OF TRANSNATIONAL RELATIONS

2020 Vol. 4 No. 2

DOI: 10.15290/eejtr.2020.04.02.03

Anna Protasiewicz ${ }^{1}$

University of Bialystok, Poland

Karolina Trzaska ${ }^{2}$

University of Bialystok, Poland

\title{
The Role of Institutions in the Technology Transfer Process with Particular Focus on Technology Parks in Poland
}

\begin{abstract}
This article addresses the issue of technology transfer in the context of institutional conditions of this process with particular focus on intermediary institutions, such as technology parks. The study presents the role of institutions in the effective process of technology transfer. The research conducted by the Polish Agency for Enterprise Development and the Association of Organizers of Innovation and Entrepreneurship Centres in Poland was used.
\end{abstract}

Keywords: technology transfer, institutions, technology parks.

\section{Introduction}

The problem of the transfer of knowledge and technology from science to industry or between enterprises constitutes a significant issue in contemporary economic research. In this context, the analysis of the appropriate management of technology, research results, transfer of knowledge and technology to business, $\mathrm{R} \& \mathrm{D}$ product marketing, but also of the conditions determining this process seems essential. The article focuses on the institutional conditions of technology transfer and concentrated especially around institutions formally described as organizations.

1 MSc, Faculty of Economics and Finance, University of Bialystok. ORCID: 0000-0003-22568273. E-mail: a.protasiewicz@uwb.edu.pl.

2 MSc, Faculty of Economics and Finance, University of Bialystok. ORCID: 0000-0002-99277389.E-mail: k.trzaska@uwb.edu.pl. 
Such entities play the role of an intermediary in the transfer process. Due to the complexity of the analysed issue, particular attention was paid to the role of technology parks. The aim of the article is to analyse the institutional environment in terms of technology transfer, with particular emphasis of technology parks in Poland and their effectiveness in this regard. It is assumed that technology parks have a decisive influence on the efficient conduct of the technology transfer process.

\section{The Concept of Technology Transfer}

Technology transfer not only comprises technology implementation but also its spread in the economy. This process is particularly important for the technological level of single entities, and consequently, the whole economy, despite the fact that the innovation based on the transferred knowledge is not an absolute novelty, it still influences the quality and speed of creating new knowledge (Różański \& Voytovych, 2019 , p. 8). Technology transfer in its most general sense is any process that aims at transferring technological know-how from a donor firm to a recipient (Günsel, 2015, p. 779). Technology transfer pertains to transfer between enterprises or science and research institutes which provide innovative solutions, and entities which demand them. The point here is not, however, passive and unconditional acceptance of technology, but gaining cognition (embodied or disembodied), and adapting it to new conditions and needs (Tylżanowski, 2017, p. 336). The term of technology transfer adopted in this paper is based on the analysis of external technology sources, consisting of transferring technology devised by other entities and applying it in one's own organization.

Technology transfer may be vertical (between science and research institutes and enterprises) or horizontal (between enterprises). Technology transfer and absorption may be paid or free which leads to its commercialization (Tylżanowski, 2014, p. 231).

The narrow approach to the term of technology transfer claims that it is "a mechanism which, through an applied agreement of the parties, causes technology spread" (UNCTAD) (UNCTAD, 2005, p. 30-31). On the other hand, the wide approach describes it as a process consisting of several stages: from creating knowledge, through technology transfer to the place where it is applied, to the acceptance and technology implementation by the final user (Ciborowski, 2016, p. 122). Therefore, this approach also comprises process conditions, which are crucial to its existence and to the effective technology transfer.

Technology transfer is certainly a multidimensional process. This term is defined in the subject literature in many ways, which results from the perception of the essence of technology transfer, which has changed through the years, as well as the perception of its subject, channels, scale and entities taking part in this process. 
A flow-system model presents six stages of technology transfer, highlighting and analysing a wide range of its aspects (Risdon, 1992):

1) creating knowledge and the concept of its practical use (it requires science and research potential as well as expenditure and taking risks);

2) codification of knowledge which enables its implementation (licences, patents, utility models, know-how, devices and equipment);

3) identification of the potential users of technology - cooperation enables the period of technology acquisition to be shortened in comparison to its independent production, minimizes the risk of failure and requires less expenditure;

4) technology transfer through appropriate channels;

5) technology implementation;

6) technology evaluation - it enables its further development or investments to be identified.

The conditions of technology transfer pace and innovation spread, therefore, include: the relative benefits of its implementation; the range of uncertainty, risk and investments connected with innovation transfer; knowledge which allows the direction of the development of innovative processes to be predicted; new, former and potential complementary solutions; formal and legal restrictions and the influence of the general environment (Ciborowski, 2016, p. 126-127).

\section{Institutional Environment of Technology Transfer}

It is possible to encounter many definitions of an institution in the subject literature. Economists from different schools have highlighted various aspects of institutional changes. According to "old" institutional economics, institutions were interpreted as widely accepted attitudes prevailing in society and customs resulting from the relation between individuals and community (T. Veblen) (Veblen, 1924, p. 101), or as a fixed and implemented in the society system of rules influencing social interactions (G.H. Hodgson) (Hodgson, 2006, p. 2). Representatives of new institutional economics, apart from informal elements, also highlight the so-called tangible aspects: informal elements including social norms, consequences, customs and routines which constitute personal codes of behaviour, while formal elements include legal rules and regulations (D.C. North) (North, 1990, p. 3-4). It should be emphasized that formal and informal institutions should complement one another. Due to the limited space of the paper, only selected formal institutions partaking in the technology transfer process in Poland were studied. In this article, the analysis of institutions has been conducted in accordance with the approach which equates institutions with organizations.

The commercialization of knowledge in the form of new technologies and products is a complicated and risky process. Knowledge and technology transfer 
(bordering between economy and science) require specialist skills and qualifications, and in reality (without any external incentives) permeates both environments with difficulty. Therefore, there is a need f institutions which regulate and support connections between scientific achievements in the field of technological progress and the real sphere of economy (Santarek, 2008, p. 109). Adaptive abilities of the economy are conditioned by the institutional environment. To reduce the barriers and risks between science and economy, certain specialized institutions are created which aim at supporting and boosting technology transfer. This paper emphasizes the importance of these units, thus of the institutions without which technology transfer process would not be possible or would be much more difficult.

Institutions play an important role, especially at the aforementioned third, fourth and fifth stage of technology transfer, that is at the phase of identifying potential technology users, and later, its transfer through appropriate channels and implementation. Therefore, it occurs in a particular economic environment, in which an important role is played by, among others, the structure of national industry, enterprises size, the structure of human or social capital (Marszałek, 2018, p. 54), as well as the kind and quality of institutions engaged in the process.

Chart 1 presents network connections within technology transfer, highlighting partaking entities. They include, on one hand, entities dealing with technology supply, on the other, those with demand for it, as well as intermediary institutions (brokers) (Hoekman et al., 2005, p. 1588-1602). The latter are, e.g. innovation support institutions, which provide a bridge (bridge institutions) between a research and development facility and an enterprise. Their activity is based on organizing knowledge transfer for creating innovation (vertical technology transfer) and its further diffusion (horizontal technology transfer) (Jasiński et al., 2019, p. 40).

\section{Chart 1.}

Network connections within technology transfer.

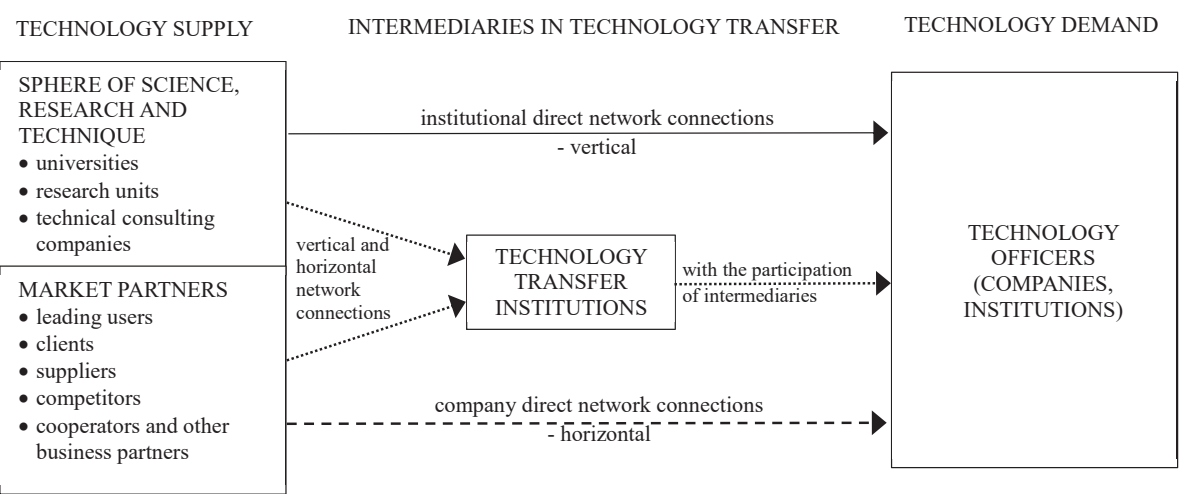

Note. Glabiszewski, W. (2016), p. 53. 
Intermediaries linking technology demand and supply within its transfer are specialized entities, which are defined as units of the technology transfer infrastructure (Jasiński, 2006, p. 23). In the context of such considerations, it is necessary to pay attention to the business environment institutions searching for buyers and transferring technologies from their creators to interested entities: technology parks, technology transfer centres and technology incubators promote technology transfer, enable its development and represent entities willing to gain new technology (Tylżanowski, 2014, p. 234-235). Simultaneous support of innovative entrepreneurship, technology transfer and knowledge commercialization need to have an integrated and complex character. The activity of such entities has to be based, on one hand, on helping to create new technological companies and helping small and medium enterprises, but also on supporting research and launching the process of transferring the results to economy. The effective support of enterprise innovation and technology transfer processes requires professional institutional background, which includes various kinds of innovation and entrepreneurship facilities. Such centres enable the distance between science and business to be reduced and scientific research with knowledge commercialization to be reconciled and new technology transfer by research institutions (Guliński \& Matusiak, 2010, p. 16-17).

Technology transfer may be, therefore, supported by institutions and institution networks. In Poland, these include various ministries responsible for innovation policy (e.g. the Ministry of Science and Higher Education, or the Ministry of Economy). Technology transfer in Poland is also stimulated by:

1) governmental and country wide institutions: Polish Agency for Enterprise Development (PARP), Industrial Development Agency (ARP), Chief Technical Organization, National Chamber of Commerce, National Contact Point, and the Patent Office of the Republic of Poland 3 ;

2) regional and local institutions for innovation and technology transfer support: technology, industry and technology, science and technology parks, technology incubators, and technology transfer centres;

3) organizationally separated units of technology transfer within the science and technology sector: Technology Transfer Centres, Academic Enterprise Incubators, the National Centre for Research and Development, the National Centre of Science, research and development units (including: Centres of Excellence and Centres of Advanced Technology (Filipiak \& Ruszała, 2009, p. 75-76);

4) foundations and associations or units appointed by them, implementing entrepreneurship development and technology transfer programmes;

3 Patent Office of the Republic of Poland developed the National Network of Patent Information Centres (facilitating access to patent information for entrepreneurs). 
5) financial institutions: National Association of Trust Funds, Polish Association of Loans Funds, Domestic Economy Bank and Domestic Capital Fund as well as local and regional loan funds.

Institutions concerned with economic order should also take into account the implementation of development directions resulting from the membership in international organizations. Arrangements concerning expectations towards integrated nations are included in the programmes (Krajowy Program Badań, 2011, p. 6): "Strategy Europe 2020", Innovation Union and Innovation Strategy OECD. The implementation of the projects' aims is conducted both at the central level (by the aforementioned units), as well as at the regional one (under Regional Operational Programmes of Voivodeships). Global development trends point to the great importance of the innovation and technology transfer development, therefore, the institutional environment is crucial and plays an important role in the development process of enterprises and the whole economy $y^{4}$.

Technology transfer from science and research facilities to enterprises using support institutions requires mutual cooperation and license issue procedures for science and research or research and development facilities (Pomykalski \& Blażlak, 2011, p. 130-144). The issue which justifies the existence of such intermediaries is the cultural distance between entrepreneurs and science and research facilities. Science institutions and universities are often accused of excessive bureaucracy and unwillingness to change or implement new organizational solutions, as well as of the lack of consideration for the practical use of research (implementation, patents, and licences). These disproportions often prevent a direct and effective technology transfer process. Intermediaries may, therefore, motivate scientists to prepare projects of new technologies targeted at industrial implementation, to raise equity for research and to start technological companies, especially academic ones (a spin-off or a spin-out).

\section{Technology Parks as Entities Supporting Technology Transfer}

A technology park is an organization managed by qualified specialists whose aim is to raise the prosperity of community where it operates through promoting innovation culture and competitiveness among entrepreneurs and knowledgebased institutions (IASP, n.d.). It is a development enterprise located near one or several universities and scientific facilities or well-connected with them. Companies which move to the park's site are usually encouraged to do so by the proximity of a university or a scientific facility but also by its attractive location.

4 Documents pointing to development trends in the world: European Commission and European Research Area (2009). 
The first technology parks were created in the 1950 s by the initiative of universities, initially as a tool of scientific policy and then of innovation. The first technology park is most often considered to be the Stanford Research Park at Stanford University, established in 1951. Silicon Valley is a source of success for the synergies between the companies and the university located there. Bohanson Research Park in Menlo Park, California, founded three years earlier, also stands out in the literature of the subject. In addition, one of the oldest parks in Europe, built in 1970, is the Cambridge Science Park. The increased emphasis on the participation of universities in industrial clusters led to a substantial spread of the idea of technology parks in the 1980s and 1990s. In addition, in the 1990s there was an intensified development of business incubators in selected industries, including pharmaceutical, ICT and biotechnology. Examples of European clusters with a long tradition include: the petrochemical sector near Antwerp, the bio-pharmaceutical sector on the DanishSwedish border, the financial services sector in London, or the flower industry in the Netherlands (Pelle et al., 2008, p. 6-7).

In the United States and Canada, the use of the term research park is widespread, in Europe it is a science park, while in Asia (Japan, China, Singapore, South Korea, Philippines, and Taiwan) it is a technology park. In Europe, science parks coexist with technology parks. While the former have a smaller scale of operation, have very strong links with academic centres and are less likely to cooperate with industry, in technology parks (much larger ones) the emphasis is mainly on manufacturing activities (Marszałek, 2019, p. 42).

In 1995 the University of Adam Mickiewicz in Poznań created the Poznan Science and Technology Park - recognized as the first technology park in Poland. The cyclical study by the International Association of Science Parks and Areas of Innovation shows that more than half of the world's science parks were established after the year 2000. Such a trend in Europe results, among others, from the policy of the European Union, which grants funds to support and develop the innovative environment. A turning point in the European policy was the creation of the European Business \& Innovation Centre Network (EBN) in 1984, which comprises around 140 Business and Innovation Centres (BIC). The aim of EBN members is to support the development of innovative entrepreneurs, start-ups and SMEs.

The first generation of science and technology parks (PNT) were built in suburban areas, and they used a linear approach to innovation. Their primary objective was to provide the conditions for the creation of science-industry relationships. (Kwieciński, 2018, p. 43). The next stage in the development of parks is linked to their stronger links with academic centres (or other research institutions), resulting in the creation of technology zones and chipping companies. On the other hand, the PNT model is currently developing as a cluster with many stakeholders operating at an international level, which is a challenge for the management staff (Annerstedt, 2006; OECD, 2011). 
The evolution of the activity of technology parks in Poland includes seven periods of their creation and development. However, it should be strongly emphasized that EU membership and access to the structural funds have particularly stimulated the development of parks (Matusiak, 2009, p. 20-22, as cited in Kwieciński, 2018, p. 45-46):

1. The pioneering period (1990-1993) - the emerging parks were a copy of Western European patterns, they were created by enthusiasts with the explicit support of foreign consultants.

2. Solving the problems of the labour market (1993-1996) - the parks created during this period were focused on structural unemployment issues, the majority of initiatives supporting entrepreneurship and not innovation or commercialization.

3. Stabilisation of the support system and new ideas (1998-2000) - a decrease in the number of parks and the first attempts to subject them to the rules of the market game, which resulted in a strong commercialisation of the service offer (office rental), but also the implementation of an innovative, promotional or internationalisation support function.

4. Pre-accession period (2001-2003) - pre-accession funds (PHARE, INTERREG) and government programmes to support entrepreneurship were already available, which revived the formation of the seeds of technology parks (dominant business incubators rather than technology incubators).

5. EU experience (2004-2007) - a dynamic increase in the number of technology parks, related to the absorption of EU structural funds (since then parks have started to fulfil the civilization function in RIS).

6. Consolidation of regional innovation systems (2008-2014) - a high liquidity in the number of technology parks, this is due to the first failures in absorbing EU funds, the lack of a sound assessment of local resources for the efficient operation of parks, as well as legislative changes that, on the one hand, intensify the pressure for pro-innovation action (e.g. new higher education regulations) and, on the other hand, 'push' some of these institutions into a rapid renaming, e.g. from an industrial park to a technological park, or into an extension of the scope of action, e.g. related to the status of a special economic zone.

7. Further consolidation and search for a business model - after the end of the next EU financial perspective 2007-2013, there is a process of freezing the number of technology parks and then slowly reducing their number. Some parks have grown to be leaders (Wrocław, Poznań, Gdynia, Gliwice), and some of them apply catch all strategies, thus fulfilling the function of a technological park, industrial park, special economic zone or zone of economic activity, to a much lesser extent fulfilling the innovative function (e.g. Bydgoszcz, Dąbrowa, Dolnośląski Park Innowacji i Nauki). 
The concept of a technology park was defined in Polish legislation in for example: Act of 20 March 2002 r. on financial support for investments (Dz.U. Nr 41, poz. 363). The act regulates the principles of granting enterprises support from public funds. Some of the concepts are also explained in the text: Act of 8 October 2004 about the principles of financing science (Dz.U. z 2004 r. Nr 238, poz. 2390 Dz.U. z 2004 r. $\mathrm{Nr} 273$, poz. 2703, Dz.U. z 2005 r. Nr 85, poz. 727). Tasks in the field of government administration in the field of supporting innovative activities within the meaning of the provisions on certain forms of supporting innovative activities are carried out by the Polish Agency for Enterprise Development (Act of 9 November 2000 on the foundation of the Polish Agency for Enterprise Development, Dz.U. z 2007 r. Nr 42, poz. $275 \mathrm{ze} \mathrm{zm}$.). In turn, the very concept of innovative activity is included in Art. 2 clause 1 point 3 of the Act of 30 May 2008 on certain forms of supporting innovative activities (Dz.U. Nr 116, poz. 730 ze zm). Until then, the included definition was valid in Act of 29 July 2005 about some forms of supporting innovative activities (Dz.U. Nr 179, poz. 1484 ze zm). In addition, there are many legal acts regulating individual aspects of the operation of technology parks. However, due to the limited scope of the study, the authors mention the most important of them.

Science and technology parks can be defined in a linear/one-sided or holistic approach. In this first perspective they are treated as instruments used in the process of technology transfer, which actively supports the process of knowledge and technology commercialization. In the interactive approach, they are seen as nodes that are part of a network of actors supporting the development of the innovative environment. Moreover, in the first sense, PNT plays the role of a kind of bridge between the new solutions created in university centres and their recipients (entrepreneurs). In a broader sense, technology transfer is seen as one of the factors ensuring development, and more attention is paid to the multifaceted relations taking place in the innovation environment (Nauwelaers et al., 2014, p. 5).

The development of technology parks is accompanied by the development of technopole agglomerations and the mechanism of progressive specialization of enterprises. The initiators of establishing parks can be both public and private entities. Increasingly, European Union countries use public-private partnership institutions to create these parks. Only a handful of technology parks operate without public support, e.g. in the United States, over $90 \%$ of business incubators are at least partially financed from public funds. In terms of the structure of expenses for R\&D purposes, Poland stands out among the EU countries on two levels. Firstly, the percentage share in GDP in Poland has one of the lowest public expenditure in terms of R\&D. Secondly, public sector investments are higher than those of private enterprises. The direct support (hereinafter BWSP) from the EU is financed mainly from the Operational Programme Innovative Economy and Regional Development Programs, and to a lesser extent by the Operational Programme Development of Eastern Poland. In nominal terms, the scale of these financing sources is relatively 
large (it amounts to $0.3-0.5 \%$ of GDP). From an economic point of view, BWSP functions mainly as an investment relief, i.e. it increases the incentives for capital accumulation and investment, which in turn increases demand for labour, employment, and finally for a product (Pelle et al., 2008, p. 18-19).

The European Union, from the beginning of its existence, has placed great emphasis on the innovation of its members, including issues concerning it in various normative acts:

1. The Treaty establishing the European Community: The Community aims to strengthen the scientific and technical attitudes of the industries of the Member States and to foster international competitiveness.

2. Green Paper on Innovation: there has been a strong criticism of the level of innovation in the European Union, while pointing out the challenges facing the Union and the measures to be taken to improve it.

3. The Lisbon Strategy: competitiveness and entrepreneurship were to contribute to economic and scientific development, while innovation was to be considered in relation to the labour market and the policy adopted with regard to SMEs (support for innovative projects and companies, reduction of administrative barriers, access to infrastructure for new companies (e.g. in the form of technology parks), access to new technologies, promotion of the idea of innovation and research, and access to financing).

4. Europe 2020: the objective continues to be to achieve economic growth through sustainable development based on three pillars: smart growth (increasing investment in R\&D and creating mechanisms and infrastructure that allow the transfer of theoretical knowledge into economic practice); sustainable growth (resource-efficient, environmentally friendly and a more competitive economy, a high-tech renewable energy sector); and inclusive growth. From the point of view of science and technology parks, the key is the first pillar, i.e. smart growth, and within this priority, the flagship project Innovation Union (e.g. development of the European Research Area, improvement of administrative conditions for conducting innovative activities by enterprises; innovative partnership at the EU level; strengthening the role of structural funds, rural development, R\&D framework programs as well as the creation of national and regional innovation systems.)

5. Numerous programs and initiatives at national and regional level.

The European Research Area (ERA) is an important element of the institutional environment of the EU countries. It represents a single, borderless market for innovation, research, and technology across the EU. The ERA provides free movement of researchers and knowledge. The ERA strengthens the alignment of countries' policies and research programs, leading to greater mutual effectiveness. 
All these activities enable better cross-border cooperation building critical mass competition across the continent (European Commission, 2020, p. 1-2).

Report of the EC points to six strategic approaches (ERAB, 2009, p. 3-10):

1) A united ERA across Europe (ensuring the free movement of ideas and people, including the use of incentives for researchers towards transnational activities).

2) An ERA driven by societal needs to address the Grand Challenges (multidisciplinary academic training, e-science tools creating a platform for the exchange of scientific experiences).

3) An ERA based on a shared responsibility between science, policy and society (providing transparency of knowledge through open access to scientific research and the validity of a universal code of scientific ethics).

4) An ERA of open innovation between all public and private stakeholders (this includes: a pan-European Open Innovation and a pan-European label, 'Open Knowledge Institution').

5) An ERA to deliver excellence (funding for public and innovative research, including $50 \%$ of high-risk frontier research).

6) An ERA of cohesion across the continent (the milestone in 2030 is to be, among others: tripling the research budget up to $12 \%$, doubling the number of people with higher education and $75 \%$ of the total budget is to go to investing in the future of the knowledge-based society).

\section{Effectiveness of Technology Parks in Poland}

Measuring the efficiency of technology parks is quite a complex process. It is difficult to measure the spectrum of parks' activities due to: the broad meaning of the concept of effectiveness (organizational and economic), differences in the development phases of parks and the diversity of their models in individual countries. It is assumed that science parks in Europe have positioned themselves as leaders in the development of the knowledge economy (Allen, 2007, p. 9). However, due to the lack of a precise and transparent system of park evaluation, the hypothesis that science parks operate effectively cannot be fully proved or rejected (Dąbrowska, 2011, p. 3-18). In addition, on the basis of global research, it cannot be clearly stated that technology parks have a positive impact on regional development. Polish parks have not operated long enough to lead to such conclusions. It is worth underlining that Wallsten's and Appold's research showed an insignificant or negative influence of technology parks on economic development in the United States (Wallsten, 2004, p. 1-15; Appold, 2004, p. 225-243). On the other hand, the positive impact on the development of regions is shown by the example of Research Triangle Park or Stanford Research. However, the institutional environment in which a given 
technology park operates is invariably crucial for the success of parks in the regional perspective, which is confirmed by many scientists, including Appold and Wallsten.

The analysis of literature concerning particular models of science and technology parks does not allow for an unambiguously positive assessment of their impact on the economy, which raises the issue of the problematic approach to the effectiveness of these entities. On the one hand, the emphasis is put on financial translation (profit achieved from investment), on the other hand, on the development of innovation (the number of start-ups, patents worked out, invented products). Undoubtedly, it is necessary to look at these aspects in a comprehensive way, taking into account conditions of local businesses (and thus the success) of science and technology parks - specific economic structure of the region (country).

Undoubtedly, from the perspective of the effectiveness of solutions contained in normative acts, coordination at the national and regional level is crucial, because the emergence of new ideas and their implementation into the economy are the result of a combination of economic, social and technical changes that create the economic space of a country, i.e. the national innovation system (NSI) (Freeman, 1987, p. 1-4). The world's dynamic science and technology clusters are characterized by the so-called bottom up approach. There is a close relationship with geographic areas with a large number of inventors and scientific authors, while having little or no relationship to administrative aspects or political boundaries (Bergquist \& Fink, 2020, p. 43).

Analysing the components of the GII (Global Innovation Index) for 2019, it is possible to assess the innovativeness of the components of the economic system in relation to other economies in the world. Poland is in the 39th place in terms of innovation.

The rule of law is classified as an income group weakness. The weaknesses of the Polish institutional environment are also: the cost of redundancy dismissal, salary weeks in regulatory environment, and the ease of starting a business in the business environment. On the other hand, the Polish economic environment also has strengths, which include the relative ease of solving insolvency issues in the business environment, and some knowledge \& technology outputs (e.g. in the category of knowledge creation: citable documents $\mathrm{H}$-index -25 th position; in the category of knowledge impact: growth rate of PPP\$ GDP/worker, \% - 18th position; in the category of knowledge diffusion: high-tech net exports, $\%$ total trade -24 th position (Dutta et al., 2020, p. 309).

According to the research on Business and Innovation Centres conducted in 2017 by the Polish Business and Innovation Centres Association, Poland is still dominated by training and consulting centres (23\%). At the end of 2017, capital funds constituted the second largest group (16\%). The smallest group among all the ones studied contained technology incubators (5\%) (Bąkowski \& Mażewska, 2018, p. 11, 15). The growing number of technology transfer centres (CTT) may result 
from the state regulations concerning universities and funds for the development of such entities. Basic tasks of such centres include, among others (Guliński \& Matusiak, 2010, p. 17): organizing science-business contacts; researching market and enterprise needs in terms of innovation; reducing the financial gap; technology transfer and providing pro-innovative services; as well as cooperation with the environment and managing intellectual property in the R\&D sector institutions. In order to acquire innovation, they emphasize individual research development or the intellectual property purchase (Trzmielak, 2013, p. 9).

The role of technology parks in the innovation system is crucial, which results, on one hand, from the fact that as non-state entities of the public sector, they connect market and public sector to fulfil functions of public utility and effectiveness. All potential stakeholders of innovative processes should take part in creating and developing technology parks, and these include: universities (shaping entrepreneurial and creative attitudes, providing innovative ideas and beginning commercialization processes), public authorities (input in the form of buildings, roads, land, funds, and supportive political climate and legal conditions), financial institutions and enterprises (supply of innovative ideas and capital). On the other hand, a technology park is the most extensive form of, so-called, business environment institutions, as their work is connected with renting an area providing laboratory equipment, financial services, as well as modern business development services (building proinnovative networks, creating partnerships, patent and legal support) (Kwieciński, 2018, p. 42).

At the beginning of 2019, Polish Business and Innovation Centres Association indicated that there are 32 technology parks in Poland. The way and range of their functioning are influenced by, among others, their location and ownership. Their placement in the country is not adequate to the technological potential as it is connected with structural problems in the economy and high unemployment in some regions. Some parks were created in large academic centres (they constitute $31 \%$ of all the centres), the rest of them were located in the cities with 60 to 250 thousand inhabitants (many of them were set up in agricultural areas). Moreover, the analysis of the parks in terms of their legal form indicates a clear dominance of Ltd. companies, joint-stock companies and JTS budgetary authorities ${ }^{5}$. However, the ownership structure does not determine the commercial character of the parks, as their common feature is a non-profit activity (Mażewska \& Tórz, 2019, p. 7-8).

In the report of the Polish Agency for Enterprise Development, it was stated that: "institutional factors determining socio-economic relations between the engaged entities and the character and effectiveness of their actions are of crucial importance for the success/failure of the technology parks initiative". Due to the fact

5 Among 22 studied parks, the structure by type in terms of legal form of business in 2019 amounted to: $41 \%$ of Ltd. companies, $27 \%$ of joint-stock companies and 27\% of Municipalities. 
that institutional factors determine the access to any resources, other elements (e.g. technical and infrastructure or financial conditions) may be regarded as secondary. Moreover, it is possible to differentiate six main factors influencing technology parks' effectiveness, i.e. (Tamowicz \& Szultka, 2005, p. 48-58):

1) critical mass - adapting the size and potential of science and research resources to the economic base needs and the adequate economic demand to the potential of the academic centre;

2) social capital - scientific community members;

3) effective partnership - inclusion of appropriate partners (public, social, and business) as a way of the enterprise legitimization and of increased access to resources (material and financial) and contacts;

4) sector matching - adapting the industrial structure of parks initiative to the real economic needs;

5) managerial profile of management - this is a factor resulting from the time conflict between the classical academic work and the increasing complexity of managerial positions. Currently, nearly all park initiatives are controlled by leaders-founders teams who are usually connected with academic institutions, which is most effective at the early stages of the park development, but may become less effective as the scale of the park initiatives increases;

6) legal formula - legal structure of the park influences the set of regulations it must follow - an Ltd. company seems to be the most beneficial one as this structure has all the essential features, such as: availability, flexibility and a right to cure, and it is also well described and analysed in judicial and legal literature. Other forms include: a foundation, an association, a finance unit or an internal project;

7) ownership and control structure - it influences the definition level of rights and obligations of entities engaged in the project, and the effectiveness of planning and of the decision-making process.

Most of the studied parks provide support services at different stages of product/ service development to different sectors of enterprises, flexibly adapting to the company needs and employing appropriate specialists (Chart 2.). 


\section{Chart 2.}

The Average Number of Services per Centre in 2018

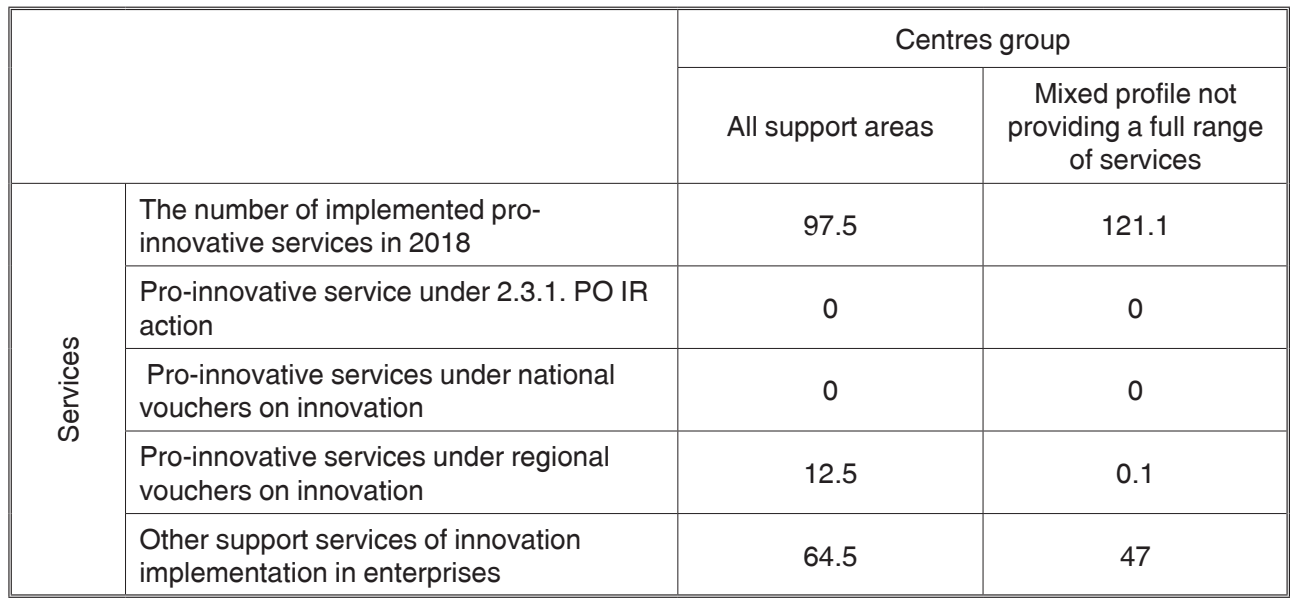

Note. Mażewska, M. \& Tórz, A. (2019), p. 33.

Among the 22 parks studied by PARP in terms of potential for offering proinnovative services, 16 parks declared the ability to provide support at the creative stage, 15 at the development stage and 12 at the implementation stage. About $77 \%$ of parks provide technical and technological support to enterprises (through: giving access to laboratories, workshops, and prototype workshops). Only $45 \%$ of centres possess facilities enabling entrepreneurs to run R\&D activity (Mażewska \& Tórz, 2019 , p. 33, 41). The above chart, presenting the number of pro-innovative services in 2018, indicates that the most active parks in terms of realizing these services are the ones providing complex and mixed services.

The crucial function of a park which constitutes an instrument of innovative policy is determining the innovation scale of enterprises located within it. Therefore, it is necessary to present the results of the research on the share of innovative companies in the total number of, so-called, park companies. The research conducted by L. Kwieciński proves that the number of innovative enterprises among all the companies operating in technology parks in Poland is relatively low $20 \%$ of innovative companies, $31 \%$ of companies with very limited tendency for creating innovation, the rest - non-innovative) (Kwieciński, 2018, p. 47-49). The meters were based on: the volume of expenditure for $R \& D$ and the percentage of companies introducing new or improved products and implementing new processes (in the production sphere).

The effective operating of technology parks depends on intellectual resources, which could be applied for commercialization, and on the entrepreneurship potential capable of transforming ideas into companies effective in the market. Technology 
parks enable the development of flexible relation networks between science and business, which makes it possible to join the needs and expectations of enterprises and the market-oriented scientific offer. Complexity of the innovative process is connected with the need to creatively integrate various technological, organizational and marketing aspects. Parks should be able to provide complex instruments supporting the commercialization of research results. In reality, they are able to create favourable conditions for effective cooperation, which leads to starting new technological companies and the improved competitiveness of the existing entities.

\section{Conclusions}

The key issue in terms of technology transfer between an academic centre and an enterprise is the finding and mutual adapting of proper entities interested in cooperation - hence, the importance of networks of mutual contacts and relationships. An equally important issue is the problem of regulating and realizing such mutual cooperation. One of the instruments which facilitates technology transfer process is the creation of technology parks, whose main aims include providing entities with technical, administrative and logistic support. To sum up, it is necessary to notice that shaping an innovative system in terms of institutional conditions should be based on internal institutional and social resources and not on imitative measures. Technology parks, which function as non-state entities of the public sector, may become a tool of effective policy.

Institutions (including organizations) are important in terms of technology transfer. Both the efficiency of formal institutions and the potential of informal institutions have a strategic impact in 3 main aspects. Firstly, when creating legal conditions for the business environment, institutions indicate the direction of development and stimulate the transfer of knowledge and technology through financial and organizational support. Due to digitization, the space for knowledge and technology transfer is becoming more and more dynamic and mobile (e.g. via online platforms). The level of digitization of the Polish economic space is still at a fairly weak level, though EU membership and the possibility to use, e.g. The ERA or technology transfer support programs largely compensate for these shortcomings. Secondly, institutions determine the growth potential of a given sector, region or country, but this cannot always be clearly confirmed, e.g. in the case of organizations such as technology parks. Thirdly, institutions in the context of some organizations (such as technology parks) are a decisive factor in the location of business enterprises, including neighbouring research units.

In conclusion, efficient institutions improve the efficiency of technology transfer, but the final impact of the activity of the stimulated organizations on the environment may vary. Therefore, whether the effect of a favourable institutional 
environment will bring positive results, such as improving the competitiveness of the region, is an open subject for further considerations on the issue of technology transfer in organizations.

\section{REFERENCES}

Allen, J. (2007). Third Generation Science Parks. Manchester: Manchester Science Parks. Retrieved from https://www.ukspa.org.uk/download/third-generation-science-parks-professor-john-allen-2007manchester-science-parks/\#.

Annerstedt, J. (2006). Science Parks and High-Tech Clustering. In: P. Bianchi \& S. Labory (Eds.), International Handbook of Industrial Policy (pp. 279-297). Cheltenham: Edward Elgar. https:// doi.org/10.4337/9781847201546.00023.

Appold, S.J. (2004). Research parks and the location of industrial research laboratories: an analysis of the effectiveness of a policy intervention. Research Policy, 33(2), 225-243. https://doi. org/10.1016/S0048-7333(03)00124-0.

Bąkowski, A. \& Mażewska, M. (Eds.) (2018). Ośrodki innowacji i przedsiębiorczości w Polsce. Raport 2018 [Innovation and entrepreneurship centres in Poland. 2018 report]. Poznań - Warszawa: Stowarzyszenie Organizatorów Ośrodków Innowacji i Przedsiębiorczości w Polsce. Retrieved from http://www.sooipp.org.pl/static/files/raport_2018.pdf.

Bergquist, K. \& Fink, C. (2020). The top 100 science and technology clusters. In S. Dutta, B. Lanvin \& S. Wunsch-Vincent (Eds.), Global Innovation Index 2020. Who Will Finance Innovation? (pp. 43-63). Ithaca - Fontainebleau - Geneva: Cornell University - INSEAD - WIPO. Retrieved from https://www.wipo.int/edocs/pubdocs/en/wipo_pub_gii_2020-chapter2.pdf.

Ciborowski, R. (2016). Międzynarodowy transfer technologii a innowacyjność krajów Europy Środkowo-Wschodniej [International technology transfer and innovation in Central and Eastern European countries]. Białystok: PTE Oddział w Białymstoku.

Dąbrowska, J. (2011). Measuring the success of science parks: performance monitoring and evaluation. Manchester: Manchester Science Park. Retrieved from https://www.cmimarseille.org/sites/ default/files/newsite/manupls/pdf4.pdf.

Dutta, S., Lanvin, B. \& Wunsch-Vincent, S. (Eds.) (2020). Global Innovation Index 2020. Who Will Finance Innovation?. Ithaca - Fontainebleau - Geneva: Cornell University - INSEAD WIPO. Retrieved from https://www.wipo.int/edocs/pubdocs/en/wipo_pub_gii_2020.pdf.

European Commission (2020). A new European Research Area. Based on excellence. Competitive, talent-driven and open. Luxembourg: Office for Official Publications of the European Communities. https://doi.org/10.2777/11151.

ERAB (2009). ERA 2030: Preparing Europe for a New Renaissance. A Strategic View of the European Research Area. Retrieved from https://www4.ffg.at/veranstaltungen/Downloads/0630E2FE. pdf.

European Commission and European Research Area (2009). Preparing Europe for a New Renaissance. A Strategic View of the European Research Area. First Report of the European Research Area Board -2009. Luxembourg: Office for Official Publications of the European Communities. Retrieved from 


\section{EASTERN EUROPEAN JOURNAL OF TRANSNATIONAL RELATIONS}

http://publications.europa.eu/resource/cellar/89724e55-9579-4bd8-80cf-9a21ba645cbc.0001.02/ DOC_1.

Filipiak, B. \& Ruszała, J. (2009). Instytucje otoczenia biznesu. Rozwój, wsparcie, instrumenty [Business environment institutions. Development, support, instruments]. Warszawa: Difin.

Freeman, Ch. (1987). Technology and Economic Performance: Lessons from Japan. London-New York: Pinter Publisher.

Glabiszewski, W. (2016). Potencjat absorpcyjny przedsiębiorstw finansowych w Polsce w procesie transferu innowacyjnych technologii [The absorptive capacity of financial companies in Poland in the process of innovative technologies transfer]. Toruń: Wydawnictwo Naukowe Uniwersytetu Mikołaja Kopernika.

Guliński, J. \& Matusiak, K.B. (Eds.) (2010). System transferu technologii i komercjalizacji wiedzy $w$ Polsce - Sity motoryczne i bariery [System of technology transfer and commercialization of knowledge in Poland. Motor forces and barriers]. Poznań-Łódź - Wrocław - Warszawa: PARP. Retrieved from https://www.parp.gov.pl/files/74/81/380/8877.pdf.

Günsel, A. (2015). Research on Effectiveness of Technology Transfer from a Knowledge Based Perspective. Procedia - Social and Behavioral Sciences, 207, 777-785. https://doi. org/10.1016/j.sbspro.2015.10.165.

Hodgson, G.M. (2006). What Are Institutions? Journal of Economic Issues, 90(1), 1-25. https://doi.org /10.1080/00213624.2006.11506879.

Hoekman, B.M., Maskus, K.E., \& Saggi, K. (2005). Transfer of Technology to Developing Countries: Unilateral and Multilateral Policy Options. World Development, 33(10), 1587-1602. https:// doi.org/10.1016/j.worlddev.2005.05.005.

IASP (n.d.). Science park. Retrieved from https://www.iasp.ws/our-industry/definitions/science-park.

Jasiński, A.H. (2006). Innowacje $i$ transfer techniki $w$ procesie transformacji [Innovation and technology transfer in the transformation process]. Warszawa: Difin.

Jasiński, A.H., Głodek, P., \& Jurczyk-Buńkowska, M. (2019). Organizacja i zarzqdzanie procesami innowacyjnymi [Organization and management of innovation processes]. Warszawa: Polskie Wydawnictwo Ekonomiczne.

Krajowy Program Badań. Założenia polityki naukowo - technicznej i innowacyjnej państwa (opracowany na podstawie art. 4 ust. 1 ustawy o zasadach finansowania nauki) [National Research Program. Assumptions of the state's science, technology and innovation policy] (2011, August 16). Załącznik do uchwały nr 164/2011 Rady Ministrów z dnia 16 sierpnia 2011 r. w sprawie ustanowienia Krajowego Programu Badań, sygn.. RM 111-156-11. Retrieved from https://www.bip.nauka.gov.pl/g2/oryginal/2013_05/ce0e785025ebbae6cd3efd3216c7761d. pdf.

Kwieciński, L. (2018). Polskie parki technologiczne - w stronę IV generacji parków technologicznych. Wstępne wyniki badań terenowych [Polish technology parks: Towards the 4th generation parks. Preliminary results of an empirical study]. Zarzqdzanie Publiczne, 1(43), 38-53. https:// doi.org/10.15678/ZP.2018.43.1.03

Marszałek, A. (2018). Parki naukowo-technologiczne jako odpowiedź na pojawiające się wyzwania ekonomiczne [Science and technology parks as a response to economic challenges]. Rozwój regionalny i polityka regionalna, 42, 49-66. Retrieved from https://pressto.amu.edu.pl/index. $\mathrm{php/rrpr/article/view/16532/16372.}$ 
Marszałek, A. (2019). Miejsce parków naukowo-technologicznych w innowacyjnym środowisku regionalnym [The position of science and technology parks within the regional innovative environment]. Rozwój Regionalny i Polityka Regionalna, 45, 41-57. https://doi.org/10.14746/ rrpr.2019.45.04.

Mażewska, M. \& Tórz, A. (Eds.) (2019). Raport z badania parków technologicznych 2019 [Report on the research of technology parks 2019]. Warszawa: Stowarzyszenie Organizatorów Ośrodków Innowacji i Przedsiębiorczości w Polsce. Retrieved from www.sooipp.org.pl/f/ N916e7m8h0W0E1m566o8N2P7v4N0j772.

Nauwelaers, C., Kleibrink, A. \& Stancova, K. (2014). The Role of Science Parks in Smart Specialisation Strategies. JRC Technical Reports. Luxembourg: Publications Office of the European Union. Retrieved from: https://publications.jrc.ec.europa.eu/repository/bitstream/JRC90719/ jrc_90719_policy\%20brief_final.pdf.

North, D.C. (1990), Institutions, Institutional Change, and Economic Performance. Cambridge: Cambridge University Press.

OECD (2011). Regions and Innovation Reviews of Regional Policy. Paris: OECD Publishing. https:// doi.org/10.1787/19976585.

Pelle, D., Bober, M. \& Lis, M. (2008). Parki technologiczne jako instrument polityki wspierania innowacji $i$ dyfuzji wiedzy [Technology parks as an instrument of innovation support and knowledge diffusion policy]. Warszawa: IBS. Retrieved from https://ibs.org.pl/app/ uploads/2016/11/IBS_Report_13_2008_pl.pdf.

Pomykalski, A. \& Blażlak, R. (2011). Zarządzanie sieciowe a innowacyjność przedsiębiorstw [Network management and innovativeness of enterprises]. In A. Bielawska-Zakrzewska (Ed.), Wyzwania rozwojowe matych $i$ średnich przedsiębiorstw. Innowacje, technologie, kryzys (ch. 8). Warszawa: Difin.

Risdon, P. (1992, December 20). Understanding the Technology Transfer Process. Vita Distribution Service, University of Pennsylvania. Retrieved from http://www.africa.upenn.edu/Comp_ Articles/Technology_Transfer_12764.html.

Różański, J. \& Voytovych, N. (2019). Transfertechnologii w procesach innowacyjnych przedsiębiorstwa [Technology transfer in enterprise innovation processes]. Łódź: Wydawnictwo Uniwersytetu Łódzkiego.

Santarek, K. (Ed.) (2008). Transfer technologii z uczelni do biznesu. Tworzenie mechanizmów transferu technologii [Technology transfer from university to business. Creation of technology transfer mechanisms]. Warszawa: PARP. https://www.parp.gov.pl/files/74/81/194/4372.pdf.

Tamowicz, P. \& Szultka, S. (2005). Parki naukowo-technologiczne w Polsce. Analiza instytucjonalnych czynników sukcesu i porażki [Science and technology parks in Poland. Analysis of institutional factors of success and failure]. In: M. Dzierżanowski, S. Szultka, P. Tamowicz, \& E. Wojnicka, Raport końcowy z badań. Analiza stanu i kierunków rozwoju parków naukowotechnologicznych, inkubatorów technologicznych i centrów transferu technologii w Polsce (pp. 45-59). Warszawa: PARP.

Trzmielak, D. (2013). Komercjalizacja wiedzy i technologii - determinanty i strategie [Knowledge and technology commercialization - stimulants and strategies]. Łódź: Wydawnictwo Uniwersytetu Łódzkiego. Retrieved from https://wydawnictwo.uni.lodz.pl/wp-content/uploads/2016/04/ Trzmielak-ebook.pdf. 


\section{EASTERN EUROPEAN JOURNAL OF TRANSNATIONAL RELATIONS}

Tylżanowski, R. (2014). Źródła transferu technologii w polskich przedsiębiorstwach [Technology transfer sources in Polish enterprises]. Studia $i$ Prace Wydziału Nauk Ekonomicznych i Zarzqdzania, 38(1), 229-238. Retrieved from https://www.wneiz.pl/nauka_wneiz/sip/sip382014/SiP-38-t1-229.pdf.

Tylżanowski, R. (2017). Wielkość przedsiębiorstwa a procesy transferu technologii w przemyśle wysokiej techniki w Polsce [The size of enterprise and technology transfer processes in hightech manufacturing sector in Poland]. Studia i Prace WNEIZ, 48(3), 333-344. http://dx.doi. org/10.18276/sip.2017.48/3-27.

UNCTAD (2005). International Investment Agreements: Key Issues. Volume III. New York and Geneva: United Nations Publication. Retrieved from https://unctad.org/system/files/ official-document/iteiit200410v3_en.pdf.

Veblen, T. (1924). Absentee Ownership and Business Enterprise in Recent Times: The Case of America. London: George Allen \& Unwin. Retrieved from https://dspace.gipe.ac.in/xmlui/ handle/10973/21673.

Wallsten, S. (2004). Do Science Parks Generate Regional Economic Growth? An Empirical Analysis of their Effects on Job Growth and Venture Capital. AEI-Brookings Joint Center Working Paper, 04-04. Retrieved from https://core.ac.uk/download/pdf/6665284.pdf. 